\title{
The effect of grazing on the fatty acid profile of longissimus thoracis muscle in Galician Blond calves
}

\author{
T. Moreno ${ }^{\dagger}$, A. Varela, C. Portela, N. Pérez, J. A. Carballo and L. Montserrat \\ Departamento de Producción Animal, Centro de Investigaciones Agrarias de Mabegondo, Apartado 10, 15080 A Coruña, Spain
}

(Received 31 July 2006; Accepted 5 June 2007)

\begin{abstract}
The objective of this work was to examine the effect of different levels of grazing on muscle nutritional fatty acid (FA) profile, including the beneficial $n-3$ polyunsaturated fatty acids (PUFA) and cis-9, trans-11 (cis-9, trans-11) 18:2 conjugated linoleic acid (CLA). Thirty male Galician Blond (GB) breed calves were randomly assigned to the following three grazing treatments:

(1) continuous pasture grazing for 250 days (P); (2) 197-day grazing followed by a 50-day short period of concentrate-based finishing $(P C)$ and (3) 57-day grazing followed by a 165-day long period of concentrate-based finishing (C). Calves kept sucking their mothers up to the time of slaughter. The slaughter weight was similar for all treatments (about $330 \mathrm{~kg}$ ). Samples of the longissimus thoracis muscle were used for assessment of chemical composition by near infrared reflectance spectroscopy and $F A$ profiles by gas chromatography. Muscle from $C$ calves was fatter and had higher content in total FA, monounsaturated FA (MUFA), cis-9 18:1 than muscle from $P$ calves, whereas $P C$ muscle had generally intermediate values. No significant treatment difference for total saturated FAs (SFA) was found. Content of potentially beneficial n-3 PUFA (18:3n-3, 20:3n-3, 20:5n-3 and 22:6n-3), cis-9, trans-11 CLA and n-6:n-3 ratio were lower and PUFA:SFA ratio were higher in $P$ than in both C and PC calves. Calves fed exclusively on pasture synthesised higher amounts of beneficial FA than calves finished on concentrate. A 50-day period of concentrate-based finishing was sufficient to offset the synthesis of beneficial FA from pasture grazing.
\end{abstract}

Keywords: CLA, grazing systems, n-3 polyunsaturated fatty acids, suckler calves

\section{Introduction}

Beef has higher proportions of saturated fatty acids (SFA) than plant food. Thus, beef is often criticised because the SFA are associated with an increased risk of obesity, hypercholesterolaemia and some cancers (Williams and Buttriss, 2006). However, beef usually contains an array of fat molecules, which have beneficial effects on human health (Moloney et al., 1999). Human diets in western countries have been recommended to be rich in 18:3n-3 polyunsaturated fatty acid (PUFA), to compensate for the perceived imbalance in the ratios of $n-6: n-3$ and PUFA : SFA (Wood et al., 2004).

Moreover, in recent years, it has been demonstrated that the conjugated linoleic acid (CLA) family has important physiological effects including anticarcinogenic, antiadipogenic, antiinflamatory and antidiabetic properties, and also the ability to reduce atherosclerosis (Pariza et al., 2001; Wahle et al., 2004; Tricon and Yagoob, 2006). Twenty different CLA isomers have been naturally found in food,

${ }^{\dagger}$ Email: teresamoreno@ciam.es especially in a variety of ruminant meats (French et al., 2000). The major CLA isomer, rumenic acid cis-9, trans-11 (cis-9, trans-11) 18:2 is produced in the rumen as a result of incomplete biohydrogenation of dietary 18:2n-6 isomer through the action of the enzyme linoleic isomerase from the ruminal bacteria (Harfoot and Hazelwood, 1997) and in tissues is synthesised from trans-11 18:1 (trans-vaccenic acid, VA) by $\Delta^{9}$-desaturase, an enzyme active in the mammary gland and in adipose tissue (Griinari et al., 2000; Mosley et al., 2006). Ruminal biohydrogenation of the predominant fatty acid (FA) in pasture (18:3n-3) also leads to production of VA and ultimately to CLA in tissue (Harfoot and Hazelwood, 1997). According to this, diets rich in these FAs should increase the concentration of CLA in the fat depot of the animal (Pariza et al., 2001). In addition, it has been shown that grazing-based diets offered to steers increased the concentration of CLA and PUFA intramuscular fat when compared with concentrate-based diets (French et al., 2000).

Traditional beef production systems in the region of Galicia, in north-west Spain, have been based on rearing small herds from the late-maturing breed Galician Blond 
(GB). This GB breed shows low development of fat depots when slaughtered at early age (7 to 9 months) (Brea et al., 1998). Calves are reared and/or finished on concentrate feed, while they are kept on maternal suckling until the time of slaughter. However, alternative systems have been designed to reduce concentrate feed costs and farming work (Moreno et al., 2006). Grazing-based beef production allows the herd size to increase and would improve animal welfare, while developing a more natural management, in accordance to several EU welfare rules (Decision 97/182/EC, Directive 97/2/EC).

Several studies have been published on the effect of different production systems on the muscle organoleptic parameters of this GB breed (Moreno, 2004; Varela et al., 2004). Nevertheless, there is a lack of information about the FA composition of the muscle of this GB breed. Likewise, there is scarcity of studies on the FA composition in suckled calves slaughtered at early age for most of the important cattle breeds, although abundant information on the FA profile is available for steers slaughtered at later ages. Thus, it is of interest to study the effect of different levels of grazing on the FA composition of muscle, including those that are beneficial for human health, in animals with a low fatness score.

\section{Material and methods}

\section{Animals and management}

Thirty male GB-breed calves from the Mabegondo Research Centre herd were used in this study. The animals were planned to be born within the interval of 1 month, between the late autumn and early winter season, and were reared with their mothers on pasture and kept sucking freely while they were grazing on a rotational system. Calves born at similar time were immediately assigned at random to each one of three different beef-finishing programmes (10 calves per treatment). Calves of undesired weight or of poor health were not selected. Treatments included different combinations of levels of pasture and concentrate feeds: (1) a continuous pasture-based grazing programme during 250 days and zero concentrate (P), (2) a period of 197 days on pasture (DP) complemented with concentrate during the last month of grazing and finished on concentrate indoors for 50 additional days (PC) and (3) a first grazing period of 57 days followed by concentrate and hay silage ad libitum diet for calves housed indoors for an additional 165 days (C). In all treatments calves kept sucking their mothers up to the time of slaughter. During the indoor period, PC and $C$, animals were housed on concrete floors covered with straw, arranged in groups of five animals per pen and were suckled by their mothers twice daily. Mothers grazed on pasture and were brought to the pens for the suckling times. In treatments $P$ and PC, calves were slaughtered 4 and 3 weeks later than the concentrate treatment $C$, respectively, to allow the animals to reach approximately the same slaughter weight (about $330 \mathrm{~kg}$ ).

Average $D P$, indoor feeding period (IFP), amount of concentrate fed indoors (CFI), hay dry-matter intake (HDMI) and silage dry-matter intake (SDMI) are shown in Table 1. Carcass fat score (FS), slaughter age (SA), slaughter weight (SW) and carcass weight (CW) of the animals used in this experiment are shown in Table 2. Concentrate and hay intakes were estimated as the difference between the daily amounts offered and refused by each animal. The type of concentrate was the same for all groups and was comprised of a mixture of barley (82\%), soya-bean meal $(13 \%)$, calcium phosphate $(2 \%)$, calcium carbonate $(1.9 \%), \mathrm{NaCl}$ $(0.8 \%)$ and mineral/vitamin mix $(0.3 \%)$. This mix was made with $94 \%$ minerals (such as $\mathrm{NaCl}, \mathrm{Ca}_{2} \mathrm{PO}_{4}, \mathrm{CaCO}_{3}, \mathrm{ZnSO}_{4}$, $\mathrm{MnSO}_{4}, \mathrm{CuSO}_{4}, \mathrm{CoSO}_{4}$; Progando, P.I.Sabón 7A, $15142 \mathrm{~A}$ Coruña, Spain) and $6 \%$ vitamins (such as vitamins $A, D_{3}, E$ and copper (II) sulphate 5-hydrate; Nutreco, Ronda Poniente, 28167 Madrid, Spain). Concentrate chemical composition is shown in Table 3.

\section{Pasture}

Ten hectares of a sward sown with a mixture of $20 \mathrm{~kg} / \mathrm{ha}$ of perennial ryegrass (Lolium perenne) and $6 \mathrm{~kg} / \mathrm{ha}$ of white clover (Trifolium repens) were offered to the animals for grazing. In spring, the animals grazed $50 \%$ of the total area, whereas the remaining $50 \%$ was reserved for the production of silage and hay to provide winter feeding complementary requirements. The sward was sown in the autumn and the fertilisation rate was 84,84 and $44 \mathrm{~kg} / \mathrm{ha}$

Table 1 Days on pasture (DP), indoor feeding period (IFP), amount of concentrate fed indoors (CFI), hay dry-matter intake (HDMI) and silage dry-matter intake (SDMI)

\begin{tabular}{lccccc}
\hline \hline & & & CFI & HDMl & SDMI \\
DP (days) & IFP (days) & (kg per animal per day) & (kg per animal per day) & (kg per (cow +calf) per day) \\
\hline Treatment $^{\ddagger}$ & & & & & 11.4 \\
P & $250(9.6)^{\dagger}$ & - & - & - & 11.4 \\
PC & $197(5.2)$ & $50(3.8)$ & 4.34 & 1.49 & - \\
C & $57(3.1)$ & $165(6.8)$ & 5.48 & 1.13 & \\
\hline \hline
\end{tabular}

${ }^{+}$Values in parenthesis indicate s.e. associated with means.

${ }^{\ddagger}$ Abbreviations are: $\mathrm{P}=$ pasture treatment; $\mathrm{PC}=$ pasture + concentrate treatment; $\mathrm{C}=$ concentrate treatment. 
Table 2 Effect of different feeding systems on least square means ${ }^{\dagger}$ of carcass fat score (FS), slaughter age (SA), slaughter weight (SW) and carcass weight (CW)

\begin{tabular}{lcccc}
\hline \hline & FS & SA (days) & SW (kg) & CW (kg) \\
\hline Treatment $^{\ddagger}$ & & & & \\
$\quad$ P & $2.9^{\mathrm{a}}(0.13)$ & $250^{\mathrm{a}}(9.6)$ & $326^{\mathrm{a}}(6.4)$ & $180^{\mathrm{a}}(4.2)$ \\
PC & $2.9^{\mathrm{a}}(0.14)$ & $247^{\mathrm{a}}(4.9)$ & $336^{\mathrm{a}}(2.4)$ & $188^{\mathrm{a}}(2.0)$ \\
$\mathrm{C}$ & $3.4^{\mathrm{b}}(0.09)$ & $222^{\mathrm{b}}(5.4)$ & $336^{\mathrm{a}}(9.8)$ & $193^{\mathrm{a}}(7.1)$ \\
\hline \hline
\end{tabular}

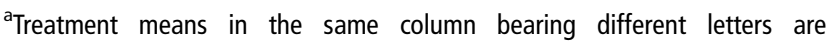
significantly different $(P<0.05)$ under the Duncan test.

${ }^{+}$Values in parenthesis indicate standard error.

${ }^{\ddagger} A$ Abbreviations are: $\mathrm{P}=$ pasture treatment; $\mathrm{PC}=$ pasture + concentrate treatment; $\mathrm{C}=$ concentrate treatment.

Table 3 Mean chemical composition of experimental feeds

\begin{tabular}{lcccc}
\hline \hline & $\begin{array}{c}\text { Hay } \\
(\%)\end{array}$ & $\begin{array}{c}\text { Grass silage } \\
(\%)\end{array}$ & $\begin{array}{c}\text { Fresh grass } \\
(\%)\end{array}$ & $\begin{array}{c}\text { Concentrate } \\
(\%)\end{array}$ \\
\hline $\begin{array}{l}\text { Characteristics } \\
\text { DM (\% fresh }\end{array}$ & 88.5 & 17.9 & 13.8 & 87.8 \\
$\begin{array}{l}\text { matter) } \\
\text { CP (\% DM) }\end{array}$ & 7.46 & 12.4 & 12.6 & 16.5 \\
OM (\% DM) & 91.4 & 88.1 & 89.3 & \\
CF (\% DM) & 27.2 & 30.1 & 22.4 & 4.55 \\
Ash (\% DM) & 7.10 & 10.8 & 12.0 & 6.77 \\
Fat (\% DM) & & & & 2.25 \\
Calcium (\% DM) & & & & 1.14 \\
FNEU (MJ/kg DM) & 5.74 & 4.30 & 7.25 & 6.75 \\
\hline \hline
\end{tabular}

${ }^{\dagger}$ Abbreviations are: $D M=$ dry matter; $F N E U=$ fattening net energy units; $\mathrm{OM}=$ organic matter; $\mathrm{CF}=$ crude fibre.

of $\mathrm{P}_{2} \mathrm{O}_{5}, \mathrm{~K}_{2} \mathrm{O}$ and $\mathrm{N}$, respectively. The maintenance fertilisation rate annually was 80,80 and $152 \mathrm{~kg} / \mathrm{ha}$ of $\mathrm{P}_{2} \mathrm{O}_{5}, \mathrm{~K}_{2} \mathrm{O}$ and $\mathrm{N}$, respectively, for the grazing area; 72, 108 and $144 \mathrm{~kg} / \mathrm{ha}$ of $\mathrm{P}_{2} \mathrm{O}_{5}, \mathrm{~K}_{2} \mathrm{O}$ and $\mathrm{N}$, respectively, for the silage and hay area. The grass silage was a first cut harvested between 20 April and 10 May with a precision-chop harvester. It was ensiled without additive in a roofed bunker covered with plastic sheets. The hay was a second cut in July from the reserved sward area with a rotary mower and using a roll baler to the hay making. The animals were grazed on a rotational system, moving into a plot when the grass height was $15 \mathrm{~cm}$. Calves were rotated using an advanced grazing system, which allowed them to select the first grass because they reached the plot before their dams. The calves left the plot when the grass was $8 \mathrm{~cm}$ high, whereas their mothers left it when it was $6 \mathrm{~cm}$ high. Grass height was measured in 40 to 50 random points on each plot by a swardstick (Barthram, 1986). Pre- and postgrazing herbage mass were estimated by cutting to ground level with a portable shearing hand-piece, eight $1-\mathrm{m}^{2}$ squares $(4 \mathrm{~cm}$ stubble height) in each ha from the sections to be grazed and last grazed by the calves. Daily herbage dry-matter (DM) intake estimated as the difference between pre- and post-grazing mass was $11.61 \mathrm{~kg} /$ day. Animals received complementary grass silage ad libitum for 77 days when grass available on pasture was limited, especially in the winter time.

A stocking rate of three animals per ha was used in the first rotation of the spring pasture, decreasing progressively in the following rotations up to one animal per ha in the late autumn pasture, as grass growth decreased and calf grazing demand increased. Chemical composition of fresh grass, grass silage and grass hay consumed by the animals were analysed once a month and is summarised in Table 3.

\section{Feed chemical composition}

Feed chemical compositions of concentrate, fresh grass, grass silage and grass hay (Table 3 ) were analysed by the Official Reference Laboratory of Galicia using gravimetric methodology for content of dry matter, and according to the International Organisation for Standardisation (ISO) methodology for animal feeding stuffs for calcium, CP, fat, crude fibre and ash (ISO 6869, 5983, 6492, 6865, 5984, respectively).

\section{Sampling procedures and measurements}

Animals were weighed before being transported $4 \mathrm{~km}$ to a commercial abattoir and slaughtered at random within $2 \mathrm{~h}$ after removal from the Research Centre in Mabegondo, A Coruña (Spain). The carcasses were weighed and classified for fat score $(1=$ leanest and $5=$ fattest $)$ according to the EU Beef Carcass Classification Scheme. After slaughtering, carcasses were hung by the Achilles tendon and were chilled for $24 \mathrm{~h}$ before sampling. Samples of the longissimus thoracis muscle between the 6th and the 10th ribs from the left side of the carcass were collected. This muscle is the reference for most of the studies. Samples were split into two $2.5-\mathrm{cm}$ thick steaks. One steak was used for assessment of chemical composition (fat content) by near infrared reflectance spectroscopy (NIRS) at $24 \mathrm{~h}$ post mortem. Another steak was used for assessment of nutritional composition (FA content) by gas chromatography. Samples were trimmed of residual fat and blended in a commercial grinder to be individually packed under vacuum (97\%) using a Technotrip model EV-15-1-CD and stored frozen at $-20^{\circ} \mathrm{C}$.

\section{Fat content analysis by NIRS}

NIRS equipment was calibrated against reference methods from the Official Reference Laboratory of Galicia for content of intramuscular fat (ISO 1443). Official Reference Laboratory of Galicia determinations were repeated three times and the means $(\mathrm{g} / 100 \mathrm{~g} \mathrm{DM})$ were the reference values for NIRS analysis. Two spectra per sample were recorded and the average spectrum was used for development of calibration equations. Two hundred samples have been previously used to develop and validate the NIRS equation (Oliete et al., 2000). 
Raw steaks were trimmed of external fat and blended in a commercial grinder. Each sample was scanned by reflectance between 1100 and $2500 \mathrm{~nm}$. Spectra of the samples were recorded on an NIR system 6500 spectrophotometer (Foss NIRSystem, Silver Spring, Washington, USA) equipped with WinISI 1.5 software (Infrasoft International, Port Matilda, PA, USA). Finally, the fat content of each sample was computed after examining the spectra and entering them into the calibration equation.

\section{FA content analysis by gas chromatography}

Samples were defrosted and homogenised with a Heidolph Diax 900 processor (Heidolph-Instruments GMBH \& COKG, Schwabach, Germany). Lipids were extracted from longissimus thoracis muscle $(50 \mathrm{~g})$ following the Bligh and Dyer (1959) method by adding $0.05 \%$ (wt/vol) butylated hydroxytoluene as an antioxidant in the $2 \%$ (vol/vol) chloroform/ methanol mixture and being homogenised with Heidolph Diax 900 homogeniser. The homogenised sample was centrifuged $(2533 \times \mathbf{g})$ for $20 \mathrm{~min}$. The liquid phase was filtered through Whatman no. 1 filter paper (Whatman Ltd., Maidstone, UK) getting a residue after filtering. The solid phase was homogenised with $50 \mathrm{ml}$ of chloroform, and then was centrifuged $(2533 \times \mathbf{g})$ before being filtered through Whatman no. 1 filter paper, getting another residue after filtering. Then $50 \mathrm{ml}$ of $\mathrm{KCl}$ were added to the filtrates, and the mixture was centrifuged $(2533 \times \mathbf{g})$ for $20 \mathrm{~min}$. The supernatant was transferred with a Pasteur pipette to an Erlenmeyer flask to be dried in a Büchi Rotavapor R-114 (Büchi Labortechnik AG, Postfach, Flawil, Switzerland). When the solvent was evaporated, the fat fraction was transferred into glass tubes. The methylation procedure of the samples were made according to the method of Morrison and Smith (1964) with slight modification, by adding $1 \mathrm{ml}$ trifluoroboron: benzene: methanol $(25: 20: 55$ $\mathrm{v} / \mathrm{v} / \mathrm{v})$ mixture. Tricosanoic acid (23:0) was added $(0.14 \mathrm{mg} /$ $\mathrm{ml}$ ) as an internal standard.

The fatty acid methyl esters (FAME) were separated by gas chromatography using a Varian 3900 GC (Varian Instruments, Walnut Creek, CA, USA) equipped with a CP-Sil 88 fused silica capillary column (Varian CP7489, $100 \mathrm{~m} \times 0.25 \mathrm{~mm}$ i.d., $0.2-\mu \mathrm{m}$ film thickness) and a Varian 8410 autosampler. The injector and the flame ionisation detector were kept at constant temperatures of $250^{\circ} \mathrm{C}$ and $260^{\circ} \mathrm{C}$, respectively. The column oven temperature was held at $70^{\circ} \mathrm{C}$ for $4 \mathrm{~min}$, increased to $110^{\circ} \mathrm{C}$ at $8^{\circ} \mathrm{C} / \mathrm{min}$, to $170^{\circ} \mathrm{C}$ at $5^{\circ} \mathrm{C} / \mathrm{min}$ and held for $10 \mathrm{~min}$, and to $240^{\circ} \mathrm{C}$ at $4^{\circ} \mathrm{C} / \mathrm{min}$ and held for $14.5 \mathrm{~min}$. The total run time was $63 \mathrm{~min}$, and the carrier gas used was He. Peaks were routinely identified based on authentic 37 FAME standard mixtures (Supelco Inc., Bellefonte, PA, USA) and CLA isomers of $c 9, t 11$ configuration not contained in that mix (Matreya Inc., Pleasant Gap, PA, USA). Our analysis achieved baseline resolution of these CLA isomers; however, no GC system can resolve all known CLA FAME (Kramer et al., 2001). The trans-7, cis-9 and trans-8, cis-10 co-elute with cis-9, trans-11.
The contribution of trans-7, cis-9 has been estimated to account for between $9 \%$ and $17 \%$ of values reported for cis-9, trans-11 concentrations in beef lipids. Quantification of FAME was based on the internal standard technique, and on the conversion of relative peaks areas into weight percentages, using the corrected response factor of each FA (ES ISO 5508).

\section{Statistical analysis}

Data were analysed by analysis of variance for a completely randomised design using the general linear model (GLM) procedure of Statistical Analysis Systems Institute (2000). It was arranged that calves were born at a similar time and weight, by discarding those born out of weight and unhealthy. A completely randomised design was used for analysis:

$$
Y_{i j}=\mu+W_{i}+\varepsilon_{i j}
$$

where $Y_{i j}$ is the observation of the production system $i$, and animal $j$ for any of the dependent variables such as intramuscular fat content and FA composition; $\mu$ is the overall mean; $W_{i}$ the effect of production system $i(i=1,2,3)$; and $\varepsilon_{i j}$ is the residual random error associated with the observation ij.

Least-square means were presented in Results section and treatment differences were considered significant at $P<0.05$.

\section{Results and discussion}

Three feeding periods were examined in this study. During the first period from birth to 57 days of age, calves from all treatments were maintained on pasture grazing. Thus, this period did not contribute to variation between treatments. During the intermediate period, animals from the P and PC treatment were kept on grazing for 143 and 140 days respectively, whereas animals from the $C$ treatment were fed on concentrate for 115 days. During the 50-day finishing period, animals on the $P$ treatment were maintained on pasture, while those from the $P$ and $C$ treatments were fed concentrates. Three main comparisons are considered for discussion: (1) differences between calves fed continuously on pasture grazing $(\mathrm{P})$ and grazing followed by concentrate (PC) tested the effect of grazing $v$. concentrate during a short finishing period; (2) differences between $\mathrm{P}$ calves and those fed mostly on concentrate (C) tested the effect of grazing $v$. concentrate during a long finishing period; and (3) differences between $P C$ and $C$ calves tested the finishing effect of a short $v$. a long concentrate period.

\section{Chemical composition}

Average values for chemical composition of the longissimus thoracis muscle are shown in Table 4. Treatment differences for protein, ash and moisture were not significant. However, slight differences $(P<0.1)$ among treatments were found 
Table 4 Chemical composition mean ${ }^{\dagger}$ of the longissimus thoracis muscle from Galician Blond calves under different feeding systems

\begin{tabular}{lrrr}
\hline \hline & \multicolumn{3}{c}{ Feeding systems $^{\ddagger}$} \\
\cline { 2 - 4 } & \multicolumn{1}{c}{$\mathrm{P}$} & $\mathrm{PC}$ & $\mathrm{C}$ \\
\hline Characteristics (\%) & & & \\
$\quad$ Moisture & $76.5^{\mathrm{a}}(0.18)$ & $76.7^{\mathrm{a}}(0.2)$ & $76.6^{\mathrm{a}}(0.29)$ \\
Ash & $1.2^{\mathrm{a}}(0.01)$ & $1.2^{\mathrm{a}}(0.01)$ & $1.2^{\mathrm{a}}(0.01)$ \\
Protein & $21.6^{\mathrm{a}}(0.16)$ & $21.8^{\mathrm{a}}(0.15)$ & $21.7^{\mathrm{a}}(0.31)$ \\
Fat & $0.4^{\mathrm{a}}(0.08)$ & $0.8^{\mathrm{b}}(0.18)$ & $0.9^{\mathrm{a}}(0.18)$ \\
\hline \hline
\end{tabular}

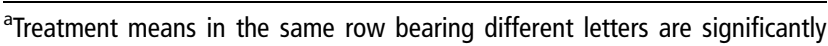
different $(P<0.05)$ under the Duncan test.

${ }^{+}$Values in parentheses indicate standard error.

${ }^{\ddagger}$ Abbreviations are: $\mathrm{P}=$ pasture treatment, $\mathrm{PC}=$ pasture + concentrate treatment, $\mathrm{C}=$ concentrate treatment.

for intramuscular fat. Calves fed only on grazing tended to have less fat than those fed on concentrate during both the short and long finishing period (Table 4). No differences in fat content were observed between short and extended periods of concentrate supplementation. These findings indicate that an even short period of concentrate feeding during finishing increased the fat depots at slaughter of young calves.

Other studies reported that different feeding systems alter the chemical composition of beef, especially in fat content (Vernon, 1986; Varela, 2002; Moreno, 2003). Small or relatively minor differences in the chemical composition of muscle may be explained by the comparable maturity and carcass weight between treatments in this experiment, in addition to the relatively early age of all calves (Table 2). A bigger increase in fat depot occurs in tissues at a later age, especially in the GB considered a late-maturing beef breed (Monserrat, 1998). Several studies have shown a positive correlation between carcass fat score and the longissimus thoracis intramuscular fat content (Kent et al., 1991; Moreno, 2003). The data collected in this study seem to indicate that carcass fat score increased (Table 2) as the intramuscular fat content increased (Table 4).

\section{FA composition}

The effect of grazing systems on the FA composition (mg/ $100 \mathrm{~g}$ muscle) of intramuscular fat in the GB muscle is shown in Table 5. A trend $(P<0.1)$ for increasing total FA as concentrate intake levels increased was found (Table 5), in concordance with the results obtained for intramuscular fat content (Table 4), following other extraction methodology. Muscle from calves fed on concentrate during the long period (C) accumulated higher total FA than calves fed on pasture grazing $(\mathrm{P})$. Our results are in agreement with other studies, which reported that an increase in total beef fat concentration was associated with an increase in MUFA (Marmer et al., 1984; Webb et al., 1998; Moreno et al., 2006).
SFA

The SFA group contributed the most to the concentration of total FA in all treatments (56.8\% to 58.3\%; Table 5). The predominant FA in this group were the $16: 0$ (35\% to $37 \%$ of total FAME) and $18: 0(12 \%$ to $13 \%)$. No significant differences among treatments were found for total SFA; however, muscle 17:0 and 18:0 content for treatment $C$ was marginally higher $(P<0.1)$ compared with animals on treatments $\mathrm{P}$ and $\mathrm{C}$. Regarding minor SFA, there were not any difference between treatments. Similar results were found by other authors in the GB breed raised on pasture (Varela et al., 2004; Moreno et al., 2006). Other studies showed that effects of feeding on SFA content depended on maturity. French et al. (2000) and Moloney et al. (2001) found higher concentration of SFA in meat from 18-monthold bulls fed on concentrates than fed on grass, whereas Enser et al. (1998) found the opposite in 12-month-old steers.

\section{MUFA}

MUFA accounted for between $30.7 \%$ and $33.1 \%$ of total FA (Table 5). Muscle from C calves had slightly higher content in total MUFA than P calves. The cis-9 $18: 1$ (27\% to $30 \%$ of total FA) was the predominant FA within this group. This reflects that the $\Delta^{9}$-desaturase enzyme has a higher affinity for 18:0 than 16:0, because the cis-9 18:1 product was higher than the 18:0 substrate, whereas cis-9 16:1 product was lower than the 16:0 substrate. Similar results were obtained by Malau-Aduli et al. (1997) and Moreno et al. (unpublished results) using early- and late-maturing breed steers.

Muscle content of cis-9 18:1 was higher in the $C$ than in the $P$ treatment. As calves consumed more concentrate and became fatter, the content of the muscle in cis-9 18:1 increased, in agreement with results of Malau-Aduli et al. (1997) and Moreno et al. (unpublished results). Muscle content of cis-9 17:1 was higher in $\mathrm{P}$ than in $\mathrm{C}$ calves, the opposite of 17:0, which was higher in $C$ than in $P$ calves. However, the sum of both 17:0 and cis-9 17:1 was similar for the three treatments.

The VA is considered as precursor of cis-9, trans-11 CLA and converted into cis-9, trans-11 CLA in tissue by the action of the $\Delta^{9}$-desaturase enzyme (Griinari et al., 2000; Mosley et al., 2006). The VA/c9t11CLA ratio showed an increasing trend from the $\mathrm{P}$ to the $\mathrm{C}$ treatment.

\section{PUFA}

The PUFA group contributed the least to the total FA ( $8.3 \%$ to $12.5 \%$ ), cis-6 $18: 2$ being the predominant PUFA (3.6\% to $4.2 \%$ of total FA) (Table 5). Similar results were found by other authors in the GB breed raised on pasture (Varela et al., 2004; Moreno et al., 2006). Muscle from P calves had higher content in total PUFA $(P<0.05)$ than PC calves. Significant differences for individual FA composition were also found among the three levels of grazing. Muscle content in the predominant cis-6 18:2 FA was higher for 
Moreno, Varela, Portela, Pérez, Carballo and Montserrat

Table 5 Effect of different feeding systems on least-square means ${ }^{\dagger}$ of main FA (mg/100 g muscle) in the longissimus thoracis muscle

\begin{tabular}{|c|c|c|c|c|}
\hline & \multicolumn{3}{|c|}{ Feeding systems } & \multirow[b]{2}{*}{$F$-test ${ }^{ \pm}$} \\
\hline & Pasture (P) & Pasture followed by concentrate (PC) & Concentrate (C) & \\
\hline \multicolumn{5}{|l|}{ FA } \\
\hline 60LE_LINK1:OLE_LINK1 & $2.28 \pm 0.40$ & $2.45 \pm 0.64$ & $2.76 \pm 0.35$ & NS \\
\hline $11: 0$ & $0.43 \pm 0.09$ & $0.56 \pm 0.11$ & $0.55 \pm 0.07$ & NS \\
\hline $13: 0$ & $1.30 \pm 0.30$ & $1.35 \pm 0.33$ & $1.06 \pm 0.15$ & NS \\
\hline $14: 0$ & $110.70 \pm 28.03$ & $120.72 \pm 26.29$ & $188.42 \pm 58.68$ & NS \\
\hline c9 14:1 & $14.22^{\mathrm{a}} \pm 2.99$ & $5.54^{b} \pm 0.87$ & $13.63^{a} \pm 2.62$ & * \\
\hline $15: 0$ & $44.79 \pm 6.01$ & $49.72 \pm 10.13$ & $51.49 \pm 4.51$ & NS \\
\hline $15: 1$ & $9.37 \pm 0.72$ & $10.93 \pm 2.24$ & $9.02 \pm 0.36$ & NS \\
\hline $16: 0$ & $749.38 \pm 41.75$ & $827.96 \pm 100.31$ & $921.37 \pm 50.58$ & NS \\
\hline c9 16:1 & $7.86 \pm 0.95$ & $10.36 \pm 1.88$ & $11.31 \pm 1.33$ & NS \\
\hline $17: 0$ & $10.61 \pm 0.62$ & $10.53 \pm 0.99$ & $13.14 \pm 0.78$ & NS \\
\hline c9 17:1 & $18.31 \pm 1.54$ & $15.33 \pm 1.81$ & $13.08 \pm 1.33$ & NS \\
\hline 18:0 & $280.51 \pm 11.16$ & $278.66 \pm 21.92$ & $330.95 \pm 14.36$ & NS \\
\hline c9 18:1 & $576.77 \pm 40.80$ & $656.42 \pm 76.41$ & $785.21 \pm 63.45$ & NS \\
\hline t9 $18: 1$ & $7.66 \pm 0.57$ & $12.10 \pm 3.27$ & $9.36 \pm 0.81$ & NS \\
\hline$t 11$ 18:1 & $14.08 \pm 0.85$ & $12.53 \pm 1.34$ & $16.35 \pm 1.63$ & NS \\
\hline c6 $18: 2$ & $81.62 \pm 7.12$ & $80.32 \pm 6.57$ & $110.65 \pm 15.73$ & NS \\
\hline t6 $18: 2$ & $1.71 \pm 0.22$ & $1.47 \pm 0.26$ & $1.43 \pm 0.23$ & NS \\
\hline$c 9 t 11 \mathrm{CLA}^{\S}$ & $8.05^{\mathrm{a}} \pm 0.36$ & $5.50^{b} \pm 0.67$ & $5.30^{b} \pm 0.39$ & ** \\
\hline $18: 3 n-6$ & $0.28 \pm 0.11$ & $0.25 \pm 0.09$ & $0.42 \pm 0.15$ & NS \\
\hline $18: 3 n-3$ & $60.48^{a} \pm 4.67$ & $28.33^{b} \pm 3.38$ & $26.99^{b} \pm 1.93$ & $* * *$ \\
\hline 20:0 & $0.74 \pm 0.28$ & $0.89 \pm 0.27$ & $1.18 \pm 0.27$ & NS \\
\hline $20: 1 n-9$ & $0.69 \pm 0.21$ & $0.43 \pm 0.19$ & $0.91 \pm 0.27$ & NS \\
\hline $20: 2 n-6$ & $1.49 \pm 0.30$ & $0.77 \pm 0.23$ & $1.04 \pm 0.39$ & NS \\
\hline $20: 3 n-3$ & $9.99^{\mathrm{a}} \pm 0.69$ & $7.28^{\mathrm{b}} \pm 0.69$ & $6.54^{b} \pm 0.41$ & $* *$ \\
\hline $20: 3 n-6$ & $1.18^{a} \pm 0.15$ & $0.58^{b} \pm 0.15$ & $0.64^{\mathrm{b}} \pm 0.17$ & * \\
\hline $20: 4 n-6$ & $21.65^{a} \pm 2.30$ & $13.53^{b} \pm 1.65$ & $22.14^{a} \pm 3.18$ & $*$ \\
\hline $20: 5 n-3$ & $38.92^{a} \pm 3.71$ & $19.07^{b} \pm 2.83$ & $20.72^{b} \pm 1.97$ & $* * *$ \\
\hline $22: 0$ & $2.19 \pm 0.18$ & $2.22 \pm 0.48$ & $2.74 \pm 0.44$ & NS \\
\hline $22: 6 n-3$ & $41.21^{a} \pm 3.12$ & $28.26^{b} \pm 3.03$ & $27.61^{b} \pm 2.67$ & $* *$ \\
\hline $23: 0$ & $0.99 \pm 0.24$ & $0.69 \pm 0.32$ & $0.36 \pm 0.24$ & NS \\
\hline $24: 0$ & $2.59 \pm 0.37$ & $1.03 \pm 0.48$ & $1.95 \pm 0.54$ & NS \\
\hline SFA & $1206.50 \pm 57.58$ & $1296.79 \pm 151.99$ & $1515.98 \pm 86.87$ & NS \\
\hline MUFA & $650.80 \pm 41.29$ & $725.71 \pm 81.28$ & $860.31 \pm 66.37$ & NS \\
\hline PUFA & $266.57^{a} \pm 19.68$ & $185.36^{\mathrm{b}} \pm 16.69$ & $223.48^{\mathrm{ab}} \pm 24.12$ & * \\
\hline$n-3$ PUFA & $150.59^{a} \pm 10.51$ & $82.94^{b} \pm 9.15$ & $81.85^{b} \pm 6.19$ & $* * *$ \\
\hline n-6 PUFA & $107.93 \pm 9.43$ & $96.92 \pm 8.24$ & $136.32 \pm 18.73$ & NS \\
\hline PUFA:SFA ratio & $0.23^{a} \pm 0.03$ & $0.15^{b} \pm 0.02$ & $0.15^{b} \pm 0.02$ & * \\
\hline n-6:n-3 ratio & $0.72^{\mathrm{a}} \pm 0.02$ & $1.23^{b} \pm 0.09$ & $1.62^{c} \pm 0.12$ & $* * *$ \\
\hline $\mathrm{VA} / \mathrm{c} 9, \mathrm{t} 11 \mathrm{CLA}$ & $1.75 \pm 0.15$ & $2.28 \pm 0.32$ & $3.08 \pm 0.65$ & NS \\
\hline Total FA & $2123 \pm 82.22$ & $2208 \pm 242.08$ & $2599 \pm 133.94$ & NS \\
\hline
\end{tabular}

Abbreviations are: $C L A=$ conjugated linoleic acid; MUFA=monounsaturated fatty acids; PUFA=polyunsaturated fatty acids; SFA=saturated fatty acids.

$\mathrm{a}, \mathrm{b}, \mathrm{c}$ Treatment means in the same row bearing different letters are significantly different under the Duncan test.

+ Values in parentheses indicate standard error.

${ }^{\ddagger}$ Symbols *** and ${ }^{* * *}$ refer to significant at $P<0.05,0.01$ and 0.001 , respectively; NS means not significant.

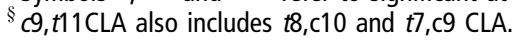

C than for both $\mathrm{P}$ and $\mathrm{PC}$ calves, which reflects a higher consumption of linoleic acid from concentrates in the $C$ group. It is also worth noting that 20:4n-6 content of muscle was higher $(P<0.05)$ in muscle of calves on $C$ than $P$ or $P C$ treatments. Furthermore, the concentrations of 20:4n-6 in muscle for the PC group were not intermediate to that in animals on $\mathrm{P}$ and $\mathrm{C}$ treatments, which might reasonably be expected based on the relative periods of grazing and concentrate feeding. FA content did not follow an additive linear model related to the level of the grazing period. It seems that a short concentrate-based finishing period of 50 days offsets the previous grazing effect on several FA, which suggests that short-term feeding systems can alter FA composition in muscle tissues (Griswold et al., 
2003). However, the 50-day concentrate finishing period was not sufficient for showing a significant effect on other MUFA and SFA relative to continuous grazing, in accordance with Duckett et al. (1993). All n-3 PUFA (i.e. 18:3n-3, $20: 3 n-3,20: 5 n-3$ and 22:6n-3) showed higher content in the $P$ calves than in either the $C$ or $P C$ calves. Consequently, total $\mathrm{n}-3$ PUFA were highly significant $(P<0.001)$ in $\mathrm{P}$ compared with $\mathrm{PC}$ and $C$ treatments. Calves fed exclusively on pasture grazing were able to synthesise higher amounts of n-3 PUFA than calves finished on concentrate, in accordance with the results of French et al. (2000), Varela et al. (2004) and Nuernberg et al. (2005). It is widely documented that 18:3 n-3 can serve as a substrate for further desaturation and elongation of PUFA (Noci et al., 2005). Even, a short concentrate period of 50 days cancelled the beneficial synthesis of the n-3 FA from pasture grazing. It seems that content of n-3 FA in muscle fat is highly influenced by the type of diet on which animals were fed during the finishing period, in accordance with other studies (Noci et al., 2005).

\section{CLA}

Cis-9, trans-11 CLA content in $\mathrm{P}$ calves was significantly higher $(P<0.01)$ than in those from both the $C$ and $P C$ treatment, whereas no differences were found between $C$ and PC (Table 5). This can be explained by the same reasons we mentioned above. During the continual oxidation and synthesis of tissue lipids, the FA profile can be expected to change over time. No apparent linear relationship between the concentration of cis-9, trans-11 CLA and VA in muscle adipose tissue was found in this study when comparing the three feeding periods. However, a positive association of VA and cis-9, trans-11 CLA seems to exist in our study when comparing $\mathrm{P}$ and $\mathrm{PC}$ treatments only. As VA increased from $P C$ to $P(12.53$ to 14.08$)$, cis-9, trans-11 CLA also increased (5.50 to 8.05 ).

\section{FA ratios}

Nutritional guidelines recommend a higher intake of $n-3$ PUFA to decrease the unbalance $n-6: n-3$ ratio consumption in western human diets (Wood et al., 2004). One possible way to achieve an acceptable balance ratio in beef is to supplement animal diets with natural sources of $n-3 F A$, specially $18: 3 n-3$, which is the most predominant FA in grass lipids (Wood and Enser, 1997). Our results clearly showed that calves raised on pasture $(\mathrm{P})$ presented healthy lower values $(P<0.001)$ for $n-6: n-3$ ratio than calves finishing on either a long or short concentrate-based period (C or PC, respectively). In addition, animal production systems based on pasture grazing are more in line within policies promoting the production of animal foods based on more extensive and welfare acceptable systems (Decision 97/182/ EC, Directive 97/2/EC).

The PUFA: SFA ratio of the muscle intramuscular fat was also higher $(P<0.05)$ in animals under the $P$ treatment
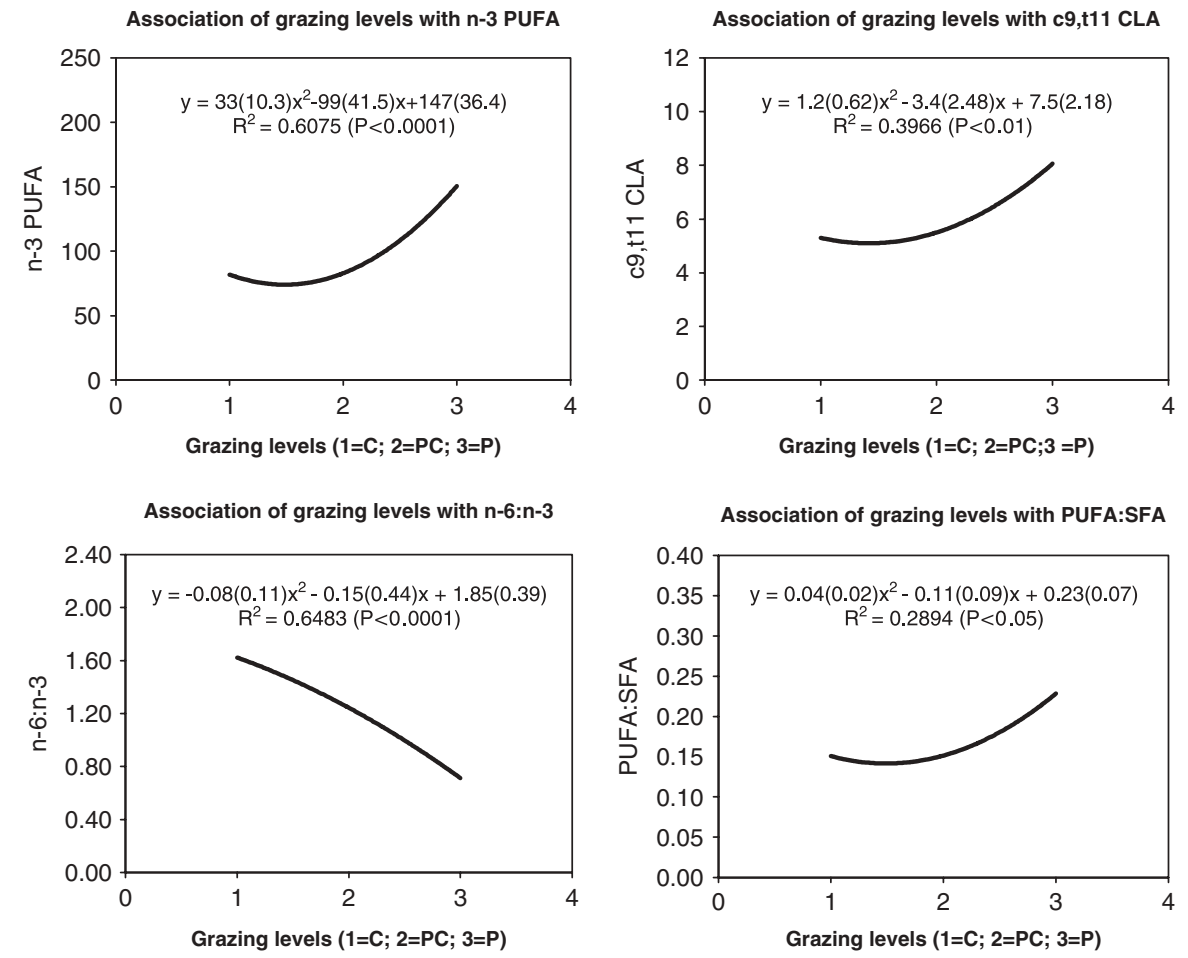

Figure 1 Second-order regression models of four beneficial fatty acid indexes (n-3 PUFA, C9t11CLA, and n-6:n-3 and PUFA: SFA ratios) on grazing levels, based on 30 intramuscular fat observations from GB breed calves. Grazing levels: $C$ refers to 57 -days grazing followed by 165 -days long concentrate-based finishing; PC refers to 197-days grazing followed by 50-days short concentrate-based finishing; and P refers to 250-days continuous grazing. The s.e. is in parentheses after the parameter estimated for each term of the model. 
compared with calves finished on concentrate ( $C$ and $P C$ ) (Table 5), in agreement with French et al. (2000), Varela et al. (2004) and Nuernberg et al. (2005). Thus, a more favourable PUFA: SFA ratio from a dietetic and health point of view was present in beef of grass-based calves $(P)$.

\section{Regression models}

Individual observations of the nutritional parameters $n-3$ PUFA, cis-9, trans-11 CLA, and n-6:n-3 and PUFA: SFA ratios were fitted to regression models on grazing levels (Figure 1). Since observed values of the parameters were generally similar for two grazing levels and differed from the other level, a second-degree polynomial best fitted the data. These second-degree polynomial regressions based on individual observations graphically illustrate and corroborate the above discussions that were based on treatment means of n-3 PUFA, cis-9, trans-11 CLA and healthy FA ratios. The regression models analysed were all statistically significant, which indicate a significant association of the grazing levels with n-3 PUFA $(P<0.0001)$, cis-9, trans-11 CLA $(P<0.01), \mathrm{n}-6: \mathrm{n}-3 \quad(P<0.0001)$ and PUFA: SFA $(P<0.05)$. The fitting of the quadratic model reflects the difference between the grazing finishing and both shortand long-term concentrate finishing for n-3 PUFA, cis-9, trans-11 CLA and PUFA: SFA.

\section{Conclusions}

Grazing enhanced the concentration of healthy FAs in muscle of young calves compared with intensive concentrate feeding systems.

\section{Acknowledgement}

This study is partially based on the doctorate thesis of the senior author to whom INIA/Spain granted a doctorate fellowship. The work was funded by INIA/Spain grant RTA01-141.

\section{References}

Barthram GT 1986. Experimental techniques: the HFRO swardstick. HFRO, biennal report, 1984-1985, pp. 29-30.

Bligh EG and Dyer WJ 1959. A rapid method of total lipid extraction and purification. Canadian Journal of Biochemistry and Physiology 37, 1911-1912.

Brea T, García J, Monserrat L, Sánchez L and Carballo JA 1998. Modelización, crecimiento y rendimiento potencial de machos y hembras de raza Rubia Gallega. Memoria CIAM 1994-1996, pp. 313-324, Xunta de Galicia.

Duckett SA, Wagner DG, Yates LD, Dolezal HG and May SG 1993. Effect of time on feed on beef nutrient composition. Journal of Animal Science 71, 2079-2088.

Enser M, Hallet K, Hewitt B, Fursey GAJ, Wood JD and Harrington G 1998. Fatty acid content and composition of UK beef and lamb muscle in relation to production system and implications for human nutrition. Meat Science 49, 329-341.

French P, Stanton C, Lawless F, O'Riordan EG, Monahan FJ, Caffrey PJ and Moloney AP 2000. Fatty acid composition, including conjugated linoleic acid, of intramuscular fat from steers offered grazed grass, grass silage, or concentrate based diets. Journal of Animal Science 78, 2849-2855.

Griinari JM, Corl BA, Lacy SH, Chouinard PY, Nurmela KVV and Bauman DE 2000. Conjugated linoleic acid is synthesized endogenously in lactating dairy cows by $\Delta^{9}$-desaturase. Journal of Nutrition 130, 2285-2291.
Griswold KE, Apgar GA, Robinson RA, Jacobson BN, Johnson D and Woody HD 2003. Effectiveness of short-term feeding strategies for altering conjugated linoleic acid content of beef. Journal of Animal Science 81, 1862-1871.

Harfoot CG and Hazelwood GP 1997. Lipid metabolism in the rumen. In The rumen microbial ecosystem, 2nd ed (ed. PN Hobson), Elsevier Science Publishing Co., Inc., New York, NY.

Kent KR, Davis GW, Ramsey CB and Schluter AR 1991. Estimates of beef carcass intermuscular fat. Journal of Animal Science 69, 4836-4844.

Kramer JKG, Cruz-Hernandez C and Zhou J 2001. Conjugated linoleic acids and octadecenoic acids: analysis by GC. European Journal of Lipid Science and Technology 103, 600-609.

Malau-Aduli AEO, Siebert BD, Bottema CDK and Pitchford WS 1997. A comparison of the fatty acid composition of triacylglycerols in adipose tissue from Limousin and Jersey cattle. Australian Journal of Agriculture Research 48, 715-722.

Marmer WN, Maxwell RJ and Williams JE 1984. Effects of dietary regimen and tissue site on bovine fatty acid profiles. Journal of Animal Science 59 109-121.

Moloney A, French P and Stanton C 1999. Grass-fed beef: a natural health food. The Irish Scientist 7, 61-65.

Moloney AP, Mooney MT, Kerry JP and Troy DJ 2001. Producing tender and flavoursome beef with enhanced nutritional characteristics. Proceedings of the Nutrition Society 60, 221-229.

Monserrat L 1998. Producción de ternero Rubio Gallego acogible a las primas de la PAC en rebaños de vacas nodrizas. Memoria CIAM 1994-1996, 291-334. Xunta de Galicia.

Moreno T 2003. Efecto del estado de engrasamiento, localización anatómica y tipo de acabado sobre el contenido e índices nutricionales de la grasa en hembras de raza Galician Blond y su cruce con Holstein-Friesian. Memoria del trabajo de investigación tutelado correspondiente a la Suficiencia Investigadora, University of Santiago de Compostela, Spain.

Moreno T 2004. Efecto de la extensificación en la calidad de la carne y de la grasa de animales acogibles a la I.G.P. Ternera Gallega. PhD thesis, University of Santiago de Compostela, Spain.

Moreno T, Varela A, Oliete B, Carballo JA, Sánchez $L$ and Monserrat $L 2006$. Nutritional characteristics of veal from weaned and unweaned calves: discriminatory ability of the fat profile. Meat Science 73, 209-217.

Morrison W and Smith LM 1964. Preparation of fatty acid methyl ester and dimethylacetals from lipids with boron fluoride methanol. Journal of Lipid Research 5, 600-608.

Mosley EE, McGuire MK, Williams JE and McGuire MA 2006. Cis-9, trans-11 conjugated linoleic acid is synthesized from vaccenic acid in lactating women. The Journal of Nutrition 136, 2297-2301.

Noci F, Monahan FJ, French $\mathrm{P}$ and Moloney AP 2005. The fatty acid composition of muscle fat and subcutaeneous adipose tissue of pasture-fed beef heifers: influence of the duration of grazing. Journal of Animal Science 83, 1167-1178.

Nuernberg K, Nuernberg G, Ender K, Dannenberger D, Schabbel W, Grumbach S, Zupp W and Steinhad H 2005. Effect of grass V. concentrate feeding on the fatty acid profile of different fat depots in lambs. European Journal of Lipid Science and Technology 107, 737-745.

Oliete B, Cardelle M and Maceiras MP 2000. Análisis de las carnes de vacuno mediante espectrofotometría del infrarrojo cercano (NIRS). Proceedings of the $\mathrm{X}$ international congress of Zootecnie, Vale de Santarem, Portugal.

Pariza MW, Park Y and Cook ME 2001. The biologically active isomers of conjugated linoleic acid. Progress in Lipid Research 40, 283-298.

Statistical Analysis Systems Institute 2000. SAS/STAT user's guidez version 8. SAS Institute Inc., Cary, NC.

Tricon S and Yagoob P 2006. Conjugated linoleic acid and human health: a critical evaluation of the evidence. Current Opinion in Clinical Nutrition and Metabolic Care 9, 105-110.

Varela A 2002. Estudio de las variables que afectan a la producción del tipo 'Cebón'. PhD thesis, University of Santiago de Compostela, Spain.

Varela A, Oliete B, Moreno T, Portela C, Monserrat L, Carballo JA and Sánchez L 2004. Effect of pasture on the meat characteristics and intramuscular fatty acid profile of steers of Rubia Gallega breed. Meat Science $67,515-522$ 
Vernon RG 1986. The growth and metabolism of adipocytes. In Control and manipulation of animal growth (ed. J Buttery, NB Haynes and DB Lindsay), pp. 67-83. Butterworths, London.

Wahle KWJ, Heys SD and Rotondo D 2004. Conjugated linoleic acids: are they beneficial or detrimental to health? Progress in Lipid Research 43, 553-587.

Webb EC, De Smet S, Van Nevel C, Martens B and Demeyer DI 1998. Effect of anatomical location on the composition of fatty acids in double-muscled Belgian Blue cows. Meat Science 50, 45-53.
Williams C and Buttriss J 2006. Improving the fat content of foods. Woodhead Publishing Ltd., Abington, Cambridge, UK.

Wood JD and Enser M 1997. Factors influencing fatty acids in meat and the role of anti-oxidants in improving meat quality. British Journal of Nutrition 78, S49-\$60.

Wood JD, Richardson RI, Nute GR, Fisher AV, Campo MM and Kasapidou PR 2004. Effects of fatty acids on meat quality: a review. Meat Science 66 , 21-32. 